Katarzyna Boratyńska

\title{
FORFEITURE OF PROPERTY IN THE LIGHT OF AMENDMENTS TO THE FISCAL PENAL CODE
}

The regulations concerning the fiscal penal law date back to the times of regaining independence by Poland . Nevertheless, the fiscal penal law was codified as late as September 10, 1999. The Fiscal Penal Code came into force to adjust the fiscal penal provisions to the following constitutional regulations: the right to hearing (Art. 45 of the Constitution of the Republic of Poland), according to which everyone shall have a right to a fair and public hearing of their case by an impartial and independent court, the principle of court administration of justice (Art. 177 of the Constitution of the Republic of Poland), which shows that the administration of justice in all matters shall be implemented by court, and the principle contained in Art. 46 of the Constitution of the Republic of Poland which reads that the property may be forfeited only by virtue of a final court judgment.

The above amendments were significant since until the year 1999 liability for fiscal offences or misdemeanours had been determined by financial authorities, therefore it is them who determined guilt or innocence against the above-mentioned constitutional provisions. However, the legislatative body left the financial authorities a possibility to fine for fiscal misdemeanours within the fine proceedings.

It seems that codifying the penal law closed the chapter of numerous amendments to the fiscal penal provisions. There is nothing more erroneous. The Fiscal Penal Code was amended 25 times within eight years and the majority of these amendements were introduced with the amendments to other acts. The exception are the amendments introduced by the Act of 24.7.2003 amending the Act - Fiscal Penal Pode, which introduced, for example, liability for the offences committed abroad affecting the financial interests of European Communities, and also extended the concept of „tax” and „taxpayer”, as well as the Act of 28.7.2005 amending the Act - Fiscal Penal Code and some other acts, which covered about $70 \%$ of the Fiscal Penal Code provisions.

Despite its broad scope the July amendments mostly adjusted the provisions of Fiscal Penal Code to the provisions of financial, currency and general penal law. 
Besides, the law-maker emphasised the priority of law enforcement over repression in the Act and strengthened the fine enforcement by imposing an obligation of auxiliary liability . These additional changes were designed to increase the effectiveness of counteracting the most dangerous fiscal crimes by imposing a penalty of deprivation of penalty by the law as well as by removing current ambiguities and irregularities regarding the legal doctrine and practical application of the fiscal penal law.

An in-depth analysis of the whole amendment from July 28, 2005 does not lie within the scope of this study and thus the focus is on the amendments related to penal remedies in the form of forfeiture of property (Art. $22 \S 2$ item 4 in conjunction with Art. 33 of the Fiscal Penal Code) and collection of pecuniary equivalent of the property subject to forfeiture (Art. $22 \S 2$ item 4 a of the Fiscal Penal Code). This choice is not accidental since the structure of provision contained in Art. 33 of the Fiscal Penal Code was changed by way of the aforementioned amendment and its purpose was to adjust it to the solutions contained in Art. 45 of the Penal Code, which in the general penal law regulates the issue of forfeiture of property. Secondly, a new kind of facilitation of proof was introduced where it was the perpetrator of a fiscal offence who was to bear the burden of producing evidence relevant to determine the origin of specific property. Thirdly, the application of the penalty of forfeiture of property toughened since the option was replaced with the obligation and the equivalent in the form of pecuniary penalty was admitted. Besides, this regulation is supported by yet another fact in the form of act of February 22, 2008 amending the Penal Code Act, the Fiscal Penal Code Act, the Code of Penal Proceedings Act, the Penal-Executive Code Act and the Press Law Act, where the instrument of property forfeiture is subject to further changes.

The forfeiture of property has as its aim to show that committing fiscal crimes is not profitable because of the obligatory decree of forfeiture of the property obtained, even indirectly, from the commission of a fiscal offence which is not subject to forfeiture. The last version of Art. 33 of the Fiscal Penal Code held that the court could decree the forfeiture of property obtained even indirectly from a fiscal offence in the case of conviction related to the penalty toughened under Art. $37 \S 1$ item 2 , that is using fiscal crime as a steady source of income, or under item 5, that is acting in an organized criminal group or organization (Art. $33 \S 1$ of the Fiscal Penal Code), and that the provisions of Art. $31 \S 4$ (Art. $33 \S 2$ of the Fiscal Penal Code) shall apply respectively.

Thus, what do the amendments to Art. 33 of the Fiscal Penal Code concern? The Act of July 28, 2005 introduced the instrument of pecuniary equivalent in place of the forfeiture of property obtained from crime, which under the Polish fiscal penal law is more concordant with the penal remedy of collecting pecuniary equivalent of the property forfeited under Art. $22 \S 2$ item 3 of the Fiscal Penal Code. Apart from 
that, as mentioned before in Art. $33 \S 2$ and 3 of the Fiscal Penal Code the legislative body introduced two proof presumptions. The first one concerns the financial benefit obtained from the commission of a fiscal offence related to the fact of possessing or having a legal title to the property during (or after) the time of committing the offence. The other relates to the ownership of property and property rights. The issues of seizing property and security on property were also regulated and a provision was introduced saying that if the property subject to forfeiture is co-owned, then the property share owned by the perpetrator shall be forfeited. Nevertheless, the penal remedy in the form of forfeiture of property or its pecuniary equivalent shall not be declared if the financial benefit is subject to restitution to another entitled entity. Additionally, unlike in the Penal Code which lets court choose between „the forfeiture of property and equivalent of its value" (Art. $45 \S 1$ of the Penal Code), the Fiscal Penal Code specifies that the pecuniary equivalent shall be collected only if the forfeiture of property is impossible.

Coming back to the issue of facilitation of proof it should be pointed out that the earlier regulations concerning the fiscal penal law provided for it, including Art. 167 of the Fiscal Penal Act from 1960 as well as Art. $166 \S 2$ of the Fiscal Penal Act from 1971, which referred to Art. $134 \S 1$ and 2 of the Penal - Executive Code from 1969. These regulations were withdrawn as a result of amendments to the 1971 Fiscal Penal Act from 1971 which took place in July 1998.

Current legal presumptions result directly from the provisions of the Fiscal Penal Code and are applicable without reference to any other legal regulations.

According to Art. $33 \S 2$ of the Fiscal Penal Code in the case of conviction for a fiscal crime from which the perpetrator obtained, even indirectly, financial benefit of substantial value, the property the perpetrator received or took possession of or received any kind of title to during or after the time of committing a fiscal offence, until passing even a non-final judgment, shall be deemed to be the financial benefit obtained from a fiscal crime, unless the perpetrator or another interested party presents evidence to the contrary thereof.

The financial benefit from the commission of an offence shall be a financial benefit obtained by the use of resources from a prohibited act and the one where legal resources are involved. In other words, the financial benefit from the commission of the offence is all property obtained from the offence, and not only the profits. Therefore, it does not seem proper to calculate the costs the perpetrator involved in a crime and then deduct them from the value of the benefit obtained.

It should be pointed out that the above-mentioned presumption is connected with the conviction for a fiscal crime from which the perpetrator gained financial benefit of substantial value (both public law, object of an offence or financial benefit liabilities), that is compliant with Art. $53 \S 15$ of the Fiscal Penal Code, the amount 
exceeding at the date of an offence 500 times the minimum wages in the meaning of the Minimum Wages Act .

This solution is thus different from the regulation contained in Art. $45 \S 2$ of the Penal Code, which refers the presumptions to the „benefit of considerable value ”, the concept not defined by the Code since Art. $115 \S 5$ of the Penal Code specifies the concept of property of considerable value, according to which it is the property whose value at the moment of committing a prohibited act exceeds 200 times the amount of the lowest minimum wage . Nevertheless, the amount of financial benefit is specified in „ordinary” evidence proceedings. A similar procedure applies to taking possession or receiving any other legal title to it during or after the time of committing an offence to the moment of passing at least a non-final judgment. Taking possession of property may appear in the form of autonomous or dependent ownership (Art. 336 of the Civil Code) or holding (Art. 336 of the Civil Code). When it comes to receiving another legal title it concerns any kind of entitlement to property, which may be the right in property or bonds and the property items may not be held by the perpetrator. On account of the fact that the legislative authority did not specify in Art. $33 \S 2$ of the Fiscal Penal Code that it concerns the first non-final judgment, the presumption also encompasses the property obtained by the perpetrator on passing the first judgment . It should be emphasized here that the presumption does not concern the perpetrator's guilt which must be proved in keeping with all the procedures.

Another facilitation of proof contained in Art. $33 \S 3$ of the Fiscal Penal Code shall apply only to the perpetrator who gained from a fiscal offence, even indirectly, the financial benefit of considerable value and it is highly probable and justified by the circumstances that this criminal benefit was transerred onto another entity. It is obvious then that the regulation provides that the benefit specified was gained during or after the time of committing a fiscal offence which is the object of proceedings, and provides for a connection, direct or indirect, between the fact of transferring the financial benefit of considerable value and taking possession of it by another entity, and the fact of committing at the specified time a fiscal crime the benefit was gained from.

The provision shall prevent the frequent phenomena of transferring the property gained from an offence onto other persons to avoid a possible forfeiture. An essential issue is to specify a "degree of probability". It should be assumed that it is estimated in the light of evidence-based proceedings, thus it should be supported by the evidence material . Only substantiating that the degree of probability is high could give a basis for the presumption. It should also be emphasized that whether the transfer of property was free of charge or not, temporary or permanent, is insignificant. Nevertheless, if a person onto whom the perpetrator transferred the 
property items derived from an offence sold them to another person, then in relation to that person the presumption under Art. $33 \S 3$ of the Fiscal Penal Code shall not apply since the forfeiture of property shall apply solely to the perpetrator and the provision of Art. $33 \S 2$ of the Fiscal Penal Code requires for the transfer to be made by the perpetrator.

In view of similar provisions contained in Art. $45 \S 3$ of the Penal Code it may be deemed that also Art. $33 \S 3$ of the Fiscal Penal Code shall be of mixed, that is of substantive and procedural nature. The procedural nature of the provision arises from regulating the procedure related to the issue of legal presumption provided for in it and the way of rebutting it, and the substantive nature is revealed in the grounds for presumption (commiting an offence referred to in Art. $33 \S 2$ of the Fiscal Penal Code, high probability of transferring onto another entity the financial benefit gained from crime by the perpetrator) and their request (the property held by another entity belongs to the perpetrator).

The legal presumptions contained in Art. $33 \S 2$ and 3 of Fiscal Penal Code are challengeable and thus may be rebutted by presenting the so-called counterevidence. It should be pointed out here that it is the perpetrator who is to show the origin of specific property and prove that it does not come from criminal activity. The reversal of burden of proof is admissable in the light of international regulations. They are provided for in, for example, Art. 5 and Art. 7 of the United Nations Convention on Illicit Traffic in Narcotic Drugs and Psychotropic Substances from December 20, 1988 and Art. 12 paragraph 7 of the United Nations Convention from November 15, 2000 Against Transnational Organized Crime . Nevertheless, the above-mentioned conventions do not impose an obligation to introduce these provisions and to ensure their compliance with the internal laws of the parties to the Convention. Additionally, they make a reservation that the adopted presumption may not infringe the property rights of third parties claiming interest in the property subject to forfeiture.

Coming back to the issue of rebutting the presumption, pursuant to Art. $33 \S 2$ of the Penal Fiscal Code, in order to challenge the presumption contained therein it is essential to present counterevidence. The requirement of presenting evidence means that one cannot recall the civil law presumption of lawful possession and it is not only substantiating a lawful possession of specific property items that is required but also about proving its lawfulness.

As far as the presumption contained in Art. $33 \S 3$ of the Fiscal Penal Code is concerned, it may be challenged if a person or another legal entity presents evidence of lawful possession of property. The evidence of lawful possession shall be the evidence of lawful acquisition by the perpetrator, that is the acquisition of property for the resources not coming from a fiscal crime. In the case if a person or organisation recalls a purchase, they should indicate the source of purchase and 
prove the origin of resources necessary to purchase it (Art. $28 \mathrm{~b} \S 2$ of the Penal Executive Code).

To sum up, counterevidence may be presented by the perpetrator or another natural person or legal entity, or an entity without legal personality on the condition that the decree of forfeiture of property refers to their rights and liabilities. Besides, in the context of substantive truth the obligation to determine all circumstances related to the instrument of legal presumption shall rely on the court and public prosecutor. It means that if the said authorities take possession of the information related to the circumstances challenging the presumption, it must be considered, which in consequence means that the presumptions are inadmissable, and in the case of, say, substantiating by the defendant the origin of property from legal sources, it will be necessary to rebut this evidence by a proceedings authority. What is more, the subject - related resources show that the presumption may not replace evidence where we have doubts regarding the thesis in question.

The facilitation of proof contained in Art. $33 \S 2$ and 3 of Fiscal Penal Code shall also apply to the seizing or securing of the property to be forfeited as well to the implementation of this remedy. Nevertheless, an individual or institution the presumption concerns may bring action against the State Treasury concerning the reversal of this allegation - until the case is settled by final judgment the whole execution proceedings shall be liable to suspension.

In conclusion, it should be pointed out that the current facilitation of proof in the form of presumptions of law were to effectively counteract the fiscal penal crime. However, as mentioned before a bill of the so-called extended forfeiture appeared. It turned out that in the opinion of bill authors the binding provisions are not sufficient to achieve the goal they were created for, that is to effectively deprive perpetrators of the property held by them or passed by them onto third parties. The proposed changes introduce, for example, the forfeiture of property from illegal sources or acquired for illegal funds. Besides, to effectively deprive perpetrators of the property they brought into conjugal community the application of presumption and forfeiture was proposed.

While evaluating these changes it should be emphasized that relying on presumption carries the danger of potential breach of substantive truth and constitutionally protected property rights. Counteracting the fiscal penal crime may not be conducted ,at every cost”, regardless of the interest subject to legal protection. 


\section{Streszczenie}

Opracowanie traktuje o instytucji przepadku korzyści majątkowej oraz ściagnięcia równowartości pieniężnej korzyści podlegającej przepadkowi w prawie karnym skarbowym. Skupiono się na przedstawieniu nowelizacji przepisu art. 33 Kodeksy karno skarbowego, której celem było dostosowanie go do rozwiązań zawartych w art. 45 Kodeksu karnego, który w prawie karnym powszechnym reguluje kwestię przepadku korzyści majątkowych. Analizie poddano rozwiązanie polegające na wprowadzeniu do prawa karnego skarbowego ułatwień dowodowych w postaci domniemania prawnego polegającego na tym, że na sprawcę przestępstwa skarbowego przerzucono ciężar dowodu w zakresie wykazania pochodzenia określonych składników majątkowych. Wskazano także na projekt nowelizacji instytucji przepadku korzyści majątkowej, w którym, między innymi w celu skuteczniejszego pozbawiania sprawców przestępstw mienia, które wnieśli oni do wspólności małżeńskiej, zaproponowano stosowanie do tego mienia domniemań oraz przepadku. 